\title{
Addressing the Impact of Atmospheric Nitrogen Deposition on Western European Grasslands
}

C.J. Stevens, D.J.G. Gowing, K.A. Wotherspoon, D. Alard, P.A. Aarrestad, A. Bleeker, R. Bobbink, M. Diekmann, N.B. Dise, C. Duprè, E. Dorland, C. Gaudnik, S. Rotthier, M.B. Soons, E. Corcket 
Addressing the Impact of Atmospheric Nitrogen Deposition on Western European Grasslands

C. J. Stevens, D. J. G. Gowing, K. A. Wotherspoon, D. Alard, P. A. Aarrestad, A. Bleeker, R. Bobbink, M. Diekmann, N. B. Dise, C. Duprè, et A Ironmental Management

ISSN 0364-152X

Volume 48

Number 5

Environmental Management (2011) 48:885-894

DOI 10.1007/s00267-011-9745-x

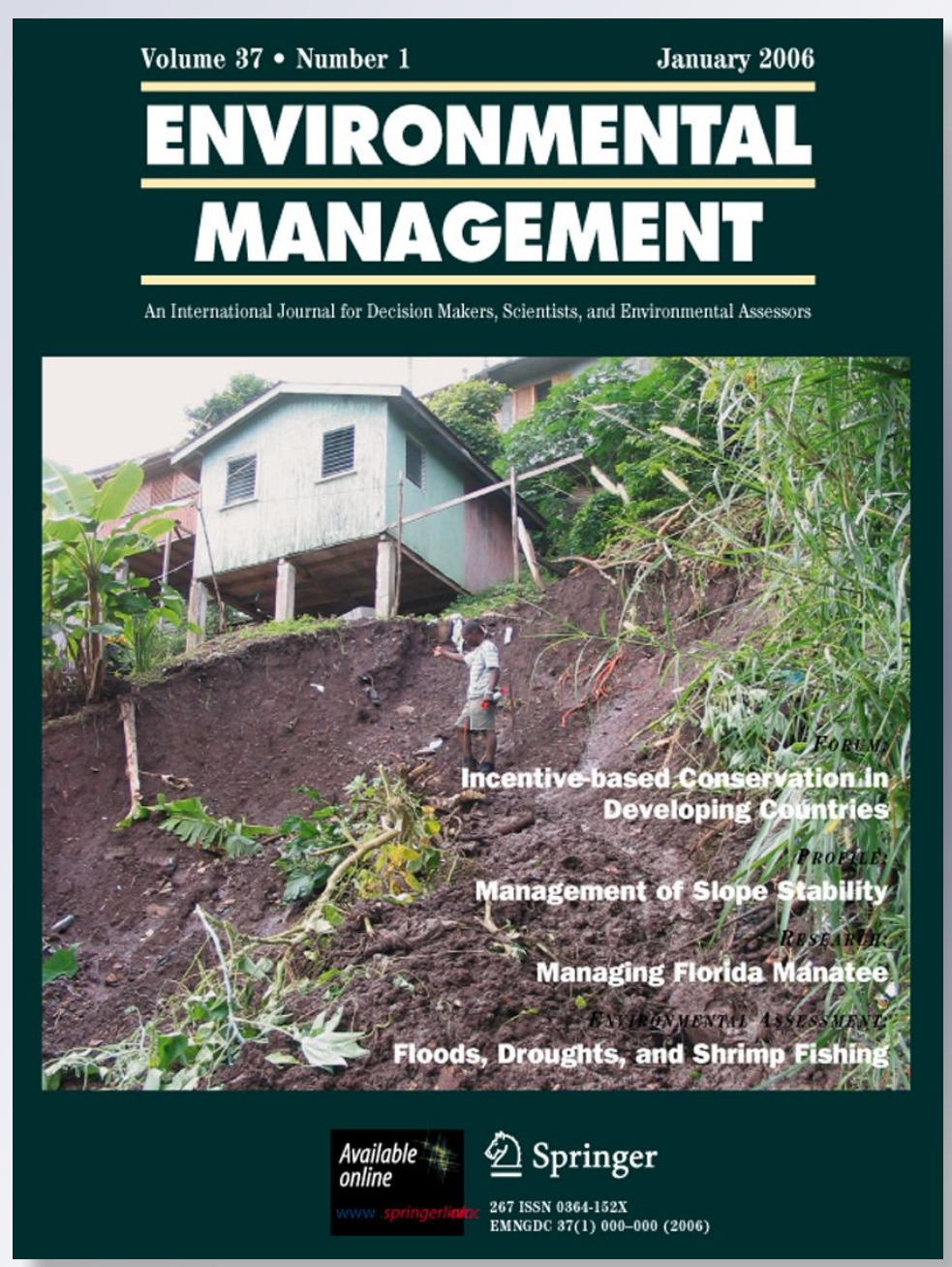

\section{包 Springer}


Your article is protected by copyright and all rights are held exclusively by Springer Science+Business Media, LLC. This e-offprint is for personal use only and shall not be selfarchived in electronic repositories. If you wish to self-archive your work, please use the accepted author's version for posting to your own website or your institution's repository. You may further deposit the accepted author's version on a funder's repository at a funder's request, provided it is not made publicly available until 12 months after publication. 


\title{
Addressing the Impact of Atmospheric Nitrogen Deposition on Western European Grasslands
}

\author{
C. J. Stevens · D. J. G. Gowing - K. A. Wotherspoon - D. Alard • \\ P. A. Aarrestad - A. Bleeker $\cdot$ R. Bobbink $\cdot$ M. Diekmann $\cdot$ N. B. Dise $\cdot$ \\ C. Duprè $\cdot$ E. Dorland $\cdot$ C. Gaudnik $\cdot$ S. Rotthier $\cdot$ M. B. Soons $\cdot$ E. Corcket
}

Received: 7 March 2011/Accepted: 16 August 2011/Published online: 8 September 2011

(C) Springer Science+Business Media, LLC 2011

\begin{abstract}
There is a growing evidence base demonstrating that atmospheric nitrogen deposition presents a threat to biodiversity and ecosystem function in acid grasslands in Western Europe. Here, we report the findings of a workshop held for European policy makers to assess the perceived importance of reactive nitrogen deposition for grassland conservation, identify areas for policy development in Europe and assess the potential for managing and mitigating the impacts of nitrogen deposition. The importance of nitrogen as a pollutant is already recognized in European legislation, but there is little emphasis in policy on the evaluation of changes in biodiversity due to nitrogen. We assess the potential value of using typical species, as defined in the European Union Habitats Directive, for determining the impact of nitrogen deposition on acid grasslands. Although some species could potentially be
\end{abstract}

C. J. Stevens $(\bowtie) \cdot$ D. J. G. Gowing · K. A. Wotherspoon

Department of Life Sciences, The Open University,

Walton Hall, Milton Keynes MK7 6AA, UK

e-mail: c.j.stevens@open.ac.uk

\section{J. Stevens}

Lancaster Environment Centre, Lancaster University,

Lancaster LA1 4YQ, UK

D. Alard · C. Gaudnik · E. Corcket

University of Bordeaux, UMR INRA 1202 Biodiversity,

Genes and Communities, Equipe Ecologie des Communautés,

Bâtiment B8, Avenue des Facultés, 33405 Talence, France

P. A. Aarrestad

Norwegian Institute for Nature Research,

PO Box 5685, Sluppen, 7485 Trondheim, Norway

A. Bleeker

Department of Air Quality \& Climate Change,

Energy Research Centre of the Netherlands,

PO Box 1, 1755 ZG Petten, The Netherlands used as indicators of nitrogen deposition, many of the typical species do not respond strongly to nitrogen deposition and are unlikely to be useful for identifying impact on an individual site. We also discuss potential mitigation measures and novel ways in which emissions from agriculture could be reduced.

Keywords Acid grasslands - Biodiversity - Convention on long-range transboundary air pollution (CLRTAP) . Nitrogen deposition · Species-rich Nardus grassland

\section{Introduction}

The natural global nitrogen $(\mathrm{N})$ cycle has been transformed by human activities as a consequence of agricultural

\author{
R. Bobbink \\ B-WARE Research Centre, Radboud University, \\ PO Box 6558, 6503 GB Nijmegen, The Netherlands \\ M. Diekmann · C. Duprè \\ Institute of Ecology, FB 2, University of Bremen, \\ Leobener Str., 28359 Bremen, Germany \\ N. B. Dise \\ Department of Environmental and Geographical Science, \\ Manchester Metropolitan University, Manchester M1 5GD, UK \\ E. Dorland · S. Rotthier - M. B. Soons \\ Ecology and Biodiversity Group, Utrecht University, \\ Padualaan 8, $3584 \mathrm{CH}$ Utrecht, The Netherlands \\ E. Dorland \\ KWR Watercycle Research Institute, \\ PO Box 1072, 3430 BB Nieuwegein, The Netherlands
}


intensification and fossil fuel combustion. Between 1860 and 1995 the global creation of reactive $\mathrm{N}$ (all forms of $\mathrm{N}$ that are biologically or photochemically active) increased from 15 to $156 \mathrm{Tg} \mathrm{N}$ year $^{-1}$. Between 1995 and 2005, it increased by a further $31-187 \mathrm{Tg} \mathrm{N}$ year $^{-1}$ (Galloway and others 2008). With continued growth of the world population and increasing demand for food, pressures on the global N cycle are set to increase (Tilman 1999).

Nitrogen oxides are mainly produced by fossil fuel combustion in transport, power generation and industrial processes whereas $90 \%$ of ammonia emissions come from agricultural sources (mainly fertilizers and animal manure) (Erisman and others 2008). Excess reactive $\mathrm{N}$ in the atmosphere is deposited to terrestrial and aquatic ecosystems as wet or dry deposition. Wet deposition occurs when soluble $\mathrm{N}$ compounds are dissolved in rain and cloud drops; dry deposition consists of gases and particles that are deposited directly to surfaces. In Europe as a whole, deposition of $\mathrm{N}$ showed a slight decline between 1980 and 2003 (Fagerli and Aas 2008), but in many areas, levels of deposition remain above those that are known to have an impact on semi-natural ecosystems. In other parts of the world, such as developing nations and growing economies, $\mathrm{N}$ deposition is increasing (Galloway and others 2008). These changes are in contrast to sulfur ( $S$ ) for which emissions have been reduced by between 90 and $70 \%$ and deposition has declined rapidly since the 1970s (Fowler and others 2007).

Atmospheric $\mathrm{N}$ deposition can potentially have a wide range of effects on semi-natural ecosystems including direct toxicity, increased sensitivity to secondary stress, acidification and eutrophication (Bobbink and others 2010). Acidification can be caused directly by acid deposition (N and $\mathrm{S}$ ), but also indirectly through leaching of basic cations, soil microbial processes and plant uptake. Increased soil acidity can result in an increased solubility of metals and a reduced availability of nutrients (Tyler and Olsson 2001). In Europe, plant species diversity tends to decline with increasing soil acidity and so species composition and richness can be impacted (Johnston and others 1986; Falkengren-Grerup 1995; Stevens and others 2004). Because $\mathrm{N}$ is the limiting nutrient in many semi-natural terrestrial ecosystems, the addition of $\mathrm{N}$ also has the potential to increase primary productivity. $\mathrm{N}$ deposition may be less of a threat where phosphorus is the limiting nutrient. For plant communities the consequence of this increase in productivity can be a shift towards domination by species with a high competitive ability under high resource availability (e.g., Bobbink and others 1998; Hautier and others 2009).

In acid grasslands (found on soils with a $\mathrm{pH}$ of around 5 or below regardless of $\mathrm{N}$ deposition status), the main effects on plant communities are a loss of species richness
(Duprè and others 2010; Maskell and others 2010; Stevens and others 2010a), especially forbs, an increase in the prevalence of competitive species (e.g., Wilson and others 1995), and an increase in the prevalence of acid tolerant species (e.g., Stevens and others 2010b) resulting in a species composition which is not typical of this community. These changes are a cause for concern because they represent a loss of biodiversity across large areas of Western Europe. Changes in plant tissue chemistry have also been observed on the gradient of deposition (Gidman and others 2006; Stevens and others 2011b).

Sala and others (2000) identified the five most important determinants of changes in biodiversity on a global scale: changes in land-use, increasing atmospheric $\mathrm{CO}_{2}$ concentration, increasing $\mathrm{N}$ deposition and acid rain, climate change, and biotic exchanges (introduction of exotic species). They used a series of scenarios of predicted future change to identify the relative effects of these drivers on biodiversity by the year 2100. For global biodiversity, land-use change was considered the greatest threat followed by climate change and $\mathrm{N}$ deposition. The relative importance of these drivers differed between habitats with $\mathrm{N}$ deposition being among the top three drivers for eight out of ten terrestrial biomes and the most important in northern temperate forests.

The Millennium Ecosystem Assessment also identified $\mathrm{N}$ and sulfur deposition together with fertilization as amongst the most important threats to biodiversity (Mace and others 2005). It concludes that $\mathrm{N}$ inputs are a threat to biodiversity at the biome and species level.

Both of these global studies are concerned with the assessment of threat to ecosystems at a global level, whereas this paper is primarily concerned with a single vegetation type (acid grassland) in Western Europe.

Semi-natural grasslands are an important component of European agriculture, supporting extensive grazing and providing hay. They also support a wide range of plant, invertebrate and bird species. Acid grasslands are found throughout Europe in both upland and lowland areas. They were formerly widespread but, in some areas of Europe, have been heavily impacted by land-use change and agricultural abandonment (Ellenberg 1996). The habitat we focus on is identified in the Conservation of Natural Habitats and of Wild Fauna and Flora Directive (92/43/EEC) (the "Habitats Directive") and is a subgroup of the Natura 2000 habitat "species-rich Nardus grassland".

Focusing on grassland systems in Western Europe, particularly acid grasslands, this paper aims to assess the perceived threat of $\mathrm{N}$ deposition to biodiversity by policy makers, identify relevant policy drivers, assess the potential for EU Habitats Directive 'typical species' to be used as indicators of $\mathrm{N}$ deposition and identify management options for mitigating the effects of $\mathrm{N}$ deposition. We also 
identify outstanding policy-related questions that scientists and policy makers need to address to effectively protect biodiversity. To do this we report on the results of a workshop held for policy makers concerned with $\mathrm{N}$ deposition in Western Europe.

\section{Perceived Importance of $\mathbf{N}$ Deposition as a Threat to Biodiversity}

In order to assess the perceived threat of $\mathrm{N}$ deposition on biodiversity we asked participants at a workshop for policy makers and others concerned with environmental policy (with a focus on national or European conservation and biodiversity policy) to give their opinions. Workshop participants came from nine countries across Western Europe (Denmark, France, Germany, Ireland, Netherlands, Norway, Sweden, Switzerland, United Kingdom). The workshop presented results of the European Science Foundation project 'BEGIN—Biodiversity of European GrasslandsImpacts of Nitrogen Deposition' and was held in October 2009 in Barsac, Gironde, France. The workshop addressed the following topics: identification of drivers of grassland habitat change, the use of indicators in assessing impacts of $\mathrm{N}$ deposition on grasslands and mitigation of impacts through responsive management. In order to assess the perceived importance of $\mathrm{N}$ deposition on grasslands we asked stakeholders at the workshop to assess the relative importance of ten drivers of biodiversity loss in grasslands ranking them from the most important (score 10) to the least important (score 1). Threats to the biodiversity of acid grasslands may differ at the Western European scale from those that we see at a global scale, so the possible drivers that delegates considered were threats specific to grassland biodiversity over the next 20 years. The candidate drivers presented for consideration by the delegates were: atmospheric $\mathrm{N}$ deposition, atmospheric sulfur deposition, intensification of agriculture (including addition of inorganic fertilizers), abandonment of management, fragmentation of habitats, climate change, overgrazing, invasion by exotic species, recreation and tourism pressures and soil compaction. There was also an option to add further drivers.

Abandonment of management was the category that was most commonly rated as the greatest threat to biodiversity (45\% of delegates), followed by intensification of agriculture and atmospheric $\mathrm{N}$ deposition. These were rated as the top three priorities for many of the delegates as can be seen by examining the average scores (Fig. 1). Afforestation and building development were both identified as a threat by one delegate each.

The high score allocated to $\mathrm{N}$ deposition reflects the perceived threat that $\mathrm{N}$ deposition presents to biodiversity.

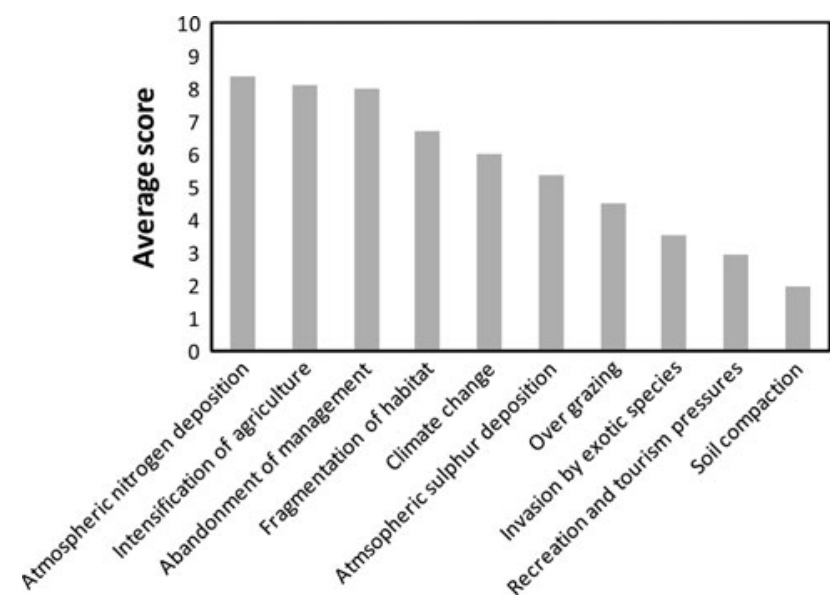

Fig. 1 Average scores allocated by 18 delegates from Western Europe to identify the most important drivers of grassland biodiversity over the next 20 years. A high score was allocated to the greatest threats

It also reflects the awareness policy makers have of the problems that $\mathrm{N}$ deposition presents. However, that these delegates participated in the workshop already indicated that they were concerned about this issue and the impacts it may be having in their countries. The results also reflect the transboundary and widespread nature of the threat presented by $\mathrm{N}$ deposition (Fagerli and Aas 2008). Differences in allocation of scores reflect personal opinion, but also national priorities and policy. In a country such as the Netherlands, where $\mathrm{N}$ deposition is well publicized and levels of deposition are high but declining as a result of successful introduction of abatement measures (Netherlands Environmental Assessment Agency 2005), we saw a higher ranking than in a country like Ireland, where $\mathrm{N}$ deposition is relatively low. In other parts of the world the perceived importance of $\mathrm{N}$ deposition as a driver of species change will vary depending on awareness and the perceived importance of other issues. For example, in Eastern Europe N deposition is high (Dentener and others 2006) and is thought to be impacting vegetation community composition (Hejcman and others 2009) but issues associated with land use change and abandonment are more likely to be considered of high priority (Sikor 2003).

\section{Nitrogen Deposition in European Policy}

The transboundary nature of $\mathrm{N}$ deposition and other air pollutants means that European legislation and international conventions are very important in dealing $\mathrm{N}$ emission and its impact on biodiversity. Key policy related to air pollution includes the Convention on long-range transboundary air pollution (CLRTAP), National Emission 
Ceilings Directive (2001/81/EC), Large Combustion Plant Directive (2000/80/EC), Ambient Air Quality Assessment and Management Directive (96/62/EC) and Integrated Pollution Prevention and Control Directive (91/61/EC and 2008/1/EC). However, although all the above directives are concerned with reducing air pollution and setting limits for $\mathrm{N}$ emissions, concentrations or deposition rates, many of these pieces of legislation do not directly consider the impact of the pollutants on semi-natural habitats. The CLRTAP is the main exception to this generalization, considering impacts on human health and environment. Indeed, of the seven International Co-operative Programmes (ICPs) reporting to the Working Group on Effects for the CLRTAP, five consider air pollution impacts on biodiversity.

The 1999 Gothenburg Protocol to abate acidification, eutrophication and ground-level ozone sets out an obligation to reduce emissions of sulfur, $\mathrm{N}$ and volatile organic compounds and ambient concentrations of ozone below specified levels. Parties are required to monitor emissions, ambient concentrations and deposition and collect information on the effects of these pollutants on human health, terrestrial and aquatic ecosystems and materials. The Gothenburg Protocol also sets out critical loads and levels for air pollutants. A critical load is defined as "a quantitative estimate of an exposure to one or more pollutants below which significant harmful effects on specified sensitive elements of the environment do not occur, according to present knowledge" (ICP Modelling and Mapping 2004; Nilsson and Grennfelt 1988). Empirical critical loads for N deposition are set for a range of habitats (Achermann and Bobbink 2003) and are based on expert knowledge and research. They consider the impacts of $\mathrm{N}$ on indicators of biodiversity, such as an increase in the dominance of $\mathrm{N}$-favored species, decreases in diversity and changes in soil chemistry. Empirical critical loads are regularly revised to take account of the most up-to-date scientific knowledge. Exceedance of these critical loads can be mapped and provide a tool for determining the potential damage of $\mathrm{N}$ deposition.

Biodiversity policy is also important for assessing the impact of $\mathrm{N}$ deposition. The UN Convention on Biological Diversity (CBD) and the Ramsar Convention both have the potential to protect habitats from the deleterious effects of $\mathrm{N}$ deposition (see Bleeker and others 2011) and criticalload exceedance for $\mathrm{N}$ deposition is used as one of the indicators in 'Streamlining European 2010 Biodiversity Indicators' (EEA 2007). Relevant European legislation includes the Directive on the Conservation of Wild Birds (2009/147/ES) and on the Habitats Directive. The Habitats Directive requires member states to take measures to ensure habitats and wild species are in a favorable conservation status.

\section{Conservation Management Tools and Options}

Detecting N Deposition Impacts Using

"Typical Species" as Indicators

In order to fulfill the requirements of the Habitats Directive, member states are required to undertake surveillance of the conservation status of the natural habitats and species and to produce a report every six years. A number of methods are used to define 'favorable status' for each habitat, including habitat range and area, and presence of typical species. Typical species are those which can be considered good indicators of favorable habitat quality, are sensitive to changes in the condition of the habitat and are detectable by non-destructive means (European Commission 2006). Typical species are defined by each member state and are species considered typical of the habitat. If these species were suitable as indicators of $\mathrm{N}$ deposition impact they would be very useful for conservation managers.

We undertook an analysis of acid grassland survey data from Western Europe to determine whether Habitats Directive typical species are suitable for use as indicators of $\mathrm{N}$ deposition. Typical species were taken from the Habitats Directive Article 17 database (EEA 2008). The most appropriate habitat classification under the Habitats Directive for the grasslands surveyed is 'species-rich Nardus grassland' (habitat code 6230). Only four countries submitted lists of typical species to the European Environment Agency for species-rich Nardus grassland in the Atlantic region: Netherlands, Ireland, France and Germany. This gave a total of 55 typical species with some species reported for more than one country (Table 1).

The data used in this analysis are from 153 species-rich Nardus grasslands in ten countries (Belgium, Denmark, France, Germany, Great Britain, Ireland, Isle of Man, Netherlands, Norway and Sweden) (Stevens and others 2010a). The grasslands surveyed were selected to cover the range of atmospheric $\mathrm{N}$ deposition in Western Europe and to give a good range of sites at different latitudes and longitudes for different deposition values. The grasslands surveyed all belonged to the association Violion caninae grassland. The definition of species-rich Nardus grassland is slightly broader than the definition of the association Violion caninae grassland (Schwickerath 1944), but Violion caninae can be considered a sub-type of the speciesrich Nardus grassland (Galvánek and Janák 2008; Krahulec 1985). Canonical correspondence analysis (CANOCO 4.5; ter Braak and Smilauer 2002) was used to show the distribution of species in relation to $\mathrm{N}$ deposition. In this ordination, $\mathrm{N}$ and sulfur (S) deposition were used as variables in the analysis whilst soil $\mathrm{pH}$, aluminum concentration, base cation concentration, nitrogen content, carbon content, C:N ratio, latitude, longitude and mean daily 
Table 1 Typical species for dry acid grassland (habitat code 6230) in the Atlantic region for countries that submitted data to the Habitats Directive Article 17 database (EEA 2008)

\begin{tabular}{|c|c|}
\hline Typical species & Country \\
\hline Achillea millefolium & IE \\
\hline Agrostis capillaris & IE \\
\hline Agrostis curtisii & FR \\
\hline Antennaria dioica & $\mathrm{DE}$ \\
\hline Anthoxanthum odoratum & IE \\
\hline Arnica montana & $\mathrm{DE}$ \\
\hline Avenula lodunensis & FR \\
\hline Botrychium lunaria & $\mathrm{DE}$ \\
\hline Carex arenaria & FR \\
\hline Carex ericetorum & NL \\
\hline Carex pallescens & $\mathrm{DE}$ \\
\hline Carex panicea & DE \\
\hline Carex pilulifera & DE, IE \\
\hline Chamaespartium sagittale & $\mathrm{DE}$ \\
\hline Dactylorhiza viridis & NL \\
\hline Danthonia decumbens & FR, IE \\
\hline Dianthus deltoides & FR \\
\hline Euphrasia stricta & $\mathrm{DE}$ \\
\hline Festuca filiformis (sub-species of $F$. ovina) & DE, FR \\
\hline Festuca ovina & IE \\
\hline Galium saxatile & DE, FR, IE, NL \\
\hline Gentiana pneumonanthe & $\mathrm{DE}$ \\
\hline Hypericum maculatum & $\mathrm{DE}, \mathrm{IE}$ \\
\hline Hypochaeris radicata & DE \\
\hline Jasione montana & FR \\
\hline Juncus squarrosus & DE, IE \\
\hline Lathyrus linifolius (synonym of L. montanus) & DE \\
\hline Lathyrus montanus & IE \\
\hline Luzula campestris & DE, FR \\
\hline Luzula multiflora & IE \\
\hline Meum athamanticum & $\mathrm{DE}$ \\
\hline Narcissus bulbocodium & FR \\
\hline Nardus stricta & DE, FR, IE, NL \\
\hline Pedicularis sylvatica & DE, FR, IE, NL \\
\hline Platanthera bifolia & $\mathrm{DE}, \mathrm{NL}$ \\
\hline Polygala serpyllifolia & DE, FR, IE, NL \\
\hline Polygala vulgaris & DE, IE \\
\hline Potentilla erecta & DE, FR \\
\hline Pseudarrhenatherum longifolium & FR \\
\hline Pseudorchis albida & IE \\
\hline Rhytidiadelphus squarrosus & IE \\
\hline Rumex acetosella & FR \\
\hline Sedum anglicum & FR \\
\hline Serapias lingua & FR \\
\hline Spiranthes spiralis & NL \\
\hline Stachys officinalis & NL \\
\hline Succisa pratensis & IE \\
\hline
\end{tabular}

Table 1 continued

\begin{tabular}{ll}
\hline Typical species & Country \\
\hline Thymus pulegioides & FR \\
Veronica officinalis & DE \\
Viola canina & DE, FR, IE \\
Viola lactea & FR \\
Viola riviniana & IE
\end{tabular}

Species in bold occurred within more than $5 \%$ of the acid grasslands surveyed

maximum temperature were used as co-variables. There were no strong geographical trends in the data (Stevens and others 2011a). For all of the sites, $\mathrm{N}$ deposition was modeled using the best available deposition model. National models were used for Germany (Gauger and others 2002), the Netherlands (Asman and van Jaarsveld 2002; Van Jaarsveld 1995, 2004) and Great Britain (NEGTAP 2001; Smith and others 2000). For all other countries, the EMEP-based IDEM model (Pieterse and others 2007) was used.

Many typical species did not occur in sufficient numbers (more than $5 \%$ of sites) in our database to be included in this ordination analysis. There are two potential reasons for this. The first is that if a species is particularly common on a regional level, but not at a broader level, they may make an ideal typical species for a country, but our dataset may not have sufficient sites within that region for it to appear in our dataset at more than $5 \%$ of all sites. The second potential reason that a typical species may not be found in our dataset is that we have not covered the full range of types of species-rich Nardus grassland as described in Natura 2000. Nevertheless, these data can give us an indication of how suitable a species may be for assessing the impact of $\mathrm{N}$ deposition.

Figure 2 shows the position of the 55 selected Article 17 typical species within an ordination diagram of a canonical correspondence analysis created using data gathered in the above-mentioned European survey. Species to the right of the ordination diagram at the top of the arrow are more commonly found at high $\mathrm{N}$ deposition (based on their occurrence and cover) within this dataset, those in the center are neutral with regards to $\mathrm{N}$ deposition and those to the left are more commonly found at lower $\mathrm{N}$ deposition. It is those species on the left that are likely to be most suitable as indicators of low nitrogen deposition impact. As can be seen from Fig. 2, typical species are scattered across the ordination diagram, so using typical species lists from the Netherlands, Ireland, France and Germany, this group of species is not suitable as an indicator of $\mathrm{N}$ deposition impact in this habitat. Analysis of each of these countries individually and comparison with national lists showed a similar scatter of typical species with respect to pollutant 


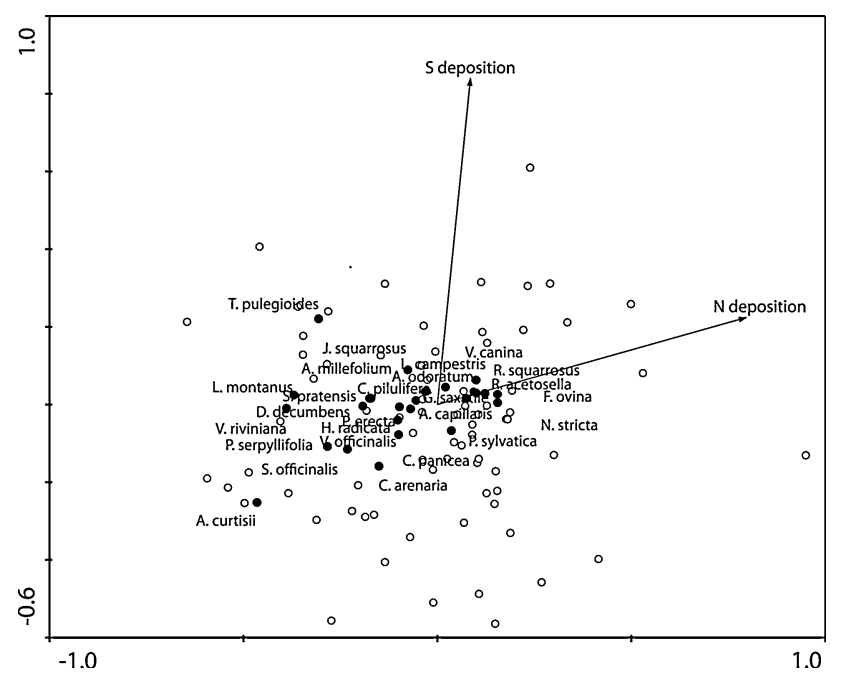

Fig. 2 Ordination diagram of a canonical correspondence analysis showing species from 153 Violion caninae grasslands in the Atlantic biogeographic region of Europe. Filled circles show Habitats Directive typical species for species-rich Nardus grassland and empty circles show other species. The empty circles have not been individually labelled for clarity; a full discussion of species associated with high and low levels of $\mathrm{N}$ deposition is given in Stevens and others (2011a). The arrows represent increasing total nitrogen deposition rate $(\mathrm{N})$ and increasing total sulfur deposition rate $(\mathrm{S})$. Eigen values for axis 1 and 2 are 0.097 and 0.276 respectively. The total inertia of the analysis was 3.79

deposition (data not shown). There are some individual species that may be suitable, most notably Agrostis curtisii (typical species in France), Stachys officinalis (typical species in the Netherlands) and Polygala serpyllifolia (typical species in Ireland and Germany). All of these species are relatively common across Western Europe (although Agrostis curtisii has a restricted distribution in the western warm oceanic regions) and so merit further investigation of their potential as indicators of $\mathrm{N}$ deposition in this particular region.

The presence or absence and abundance of most typical species are not suitable indicators of $\mathrm{N}$ deposition at a Western European scale, indeed, many of the species selected as typical species are too common to be useful indicators even at a national scale. Given the widespread nature of this result in Western Europe it is likely that this will be true throughout the whole of Europe. Alternative species may provide more suitable indicators although other measures such as Ellenberg $\mathrm{N}$ scores, species richness or grass:forb ratio may be more useful, particularly if temporal changes in these measures could be assessed (Duprè and others 2010; Stevens and others 2009).

\section{Mitigation of Acidification and Eutrophication}

Detecting the potential impacts of atmospheric $\mathrm{N}$ deposition is only the initial stage of dealing with the problem.
Once affected sites are identified, appropriate management should be put in place to mitigate the effects of deposition. There are a number of different options for the management of grasslands to control the impact of $\mathrm{N}$ deposition. These fall into two categories, measures to mitigate acidification and measures to mitigate eutrophication.

The main method of mitigating soil acidification is liming. Liming has a long history of use in agricultural sciences, indeed the Park Grass Experiment at Rothamsted Experimental Station in Hertfordshire, England commenced experimental lime addition in 1903 (Silvertown and others 1994). Liming has been widely used to combat acidification from atmospheric pollutants and nutrient addition in many habitats, including grasslands (e.g., Blake and others 1999; De Graaf and others 1998). Lime (usually calcium carbonate) reduces soil acidity by exchange of calcium or magnesium ions with hydrogen ions on soil particles resulting in a higher soil $\mathrm{pH}$. In a heathlandcatchment liming experiment, Dorland and others (2005b) found liming resulted in higher soil $\mathrm{pH}$, higher concentrations of base cations and a reduced $\mathrm{Al}$ :Ca ratio. Despite this, there was only a small positive response by vegetation, but changes in species composition were observed including the cessation of vigorous growth of some competitive species and an increase in rarer species. The addition of too much lime can damage plants and the effects if liming can vary depending on the site history, soil type, amount of $\mathrm{N}$ in the soil and the plant species present. In areas fed by base-rich groundwater, raising water-tables in the soil has also been used to combat acidification (Roelofs and others 1996).

Where species composition is changing as a result of eutrophication and consequent increases in productivity, measures can be taken to reduce competition for light and to remove nitrogen from the system. These could include an increase in cutting frequency or grazing intensity. These methods are commonly used in the restoration of grassland from former agricultural land (Walker and others 2003) and can change species composition, reducing the cover of productive grasses promoted by the addition of N. Additional winter grazing to disturb the grassland turf is also an option (Jones and Hayes 1999). The removal of biomass by cutting and taking off the hay also removes $\mathrm{N}$ from the system with the potential to reduce nutrient status of the soil and reduce productivity in the long-term. However, the rate of nutrient removal by this method is usually low (Hejcman and others 2010), and so it may take some time for a significant change to be detected (Olff and Bakker 1991). Burning also provides a means of biomass removal and is traditionally used as a management tool in some habitats (e.g., heathlands) but it is not commonly used in grasslands and may not be well accepted by the general public, because it produces greenhouse gases, particulate 
pollution and other air pollutants, leaves large areas looking unsightly and generates safety concerns. Another method that has been tested experimentally for the removal of reactive $\mathrm{N}$ from soils is the addition of carbon (C). C addition in the form of sucrose, sawdust, starch or cellulose increases the $\mathrm{C}: \mathrm{N}$ ratio of soil and can induce microbial communities to immobilize $\mathrm{N}$ in the soil, thus making it inaccessible to plants (e.g., Eschen and others 2007; Török and others 2000).

Turf stripping or cutting is the most dramatic method for the removal of nutrients, but it also removes acidified surface soil, and so can address both acidification and eutrophication problems. Turf stripping has been used extensively in some countries, especially the Netherlands, for the restoration of heathland (De Graaf and others 1998; Dorland and others 2005a). Topsoil removal is an alternative method that has been used for the restoration of grasslands (e.g., Buisson and others 2006) but it presents similar problems to turf stripping. Although turf stripping has undergone experimental trials in grasslands (e.g., Jansen and Roelofs 1996; Pywell and others 2002), it is an expensive form of management and in addition to removing nutrients and acidified soil, it also removes the soil seed bank and organic matter, as well as reducing the water holding capacity of the soil (van den Berg and others 2003a). The removal of the soil seed bank means that if the local species pool is already depleted, appropriate species may not be able to re-colonize and may need to be reintroduced (Dorland and others 2004; van den Berg and others 2003b). Dispersal into large cleared areas is usually not sufficient for rapid colonization by target species, and would require large source populations nearby. For perennial species that do not produce large annual seed crops, unassisted dispersal is likely to be quite limited (e.g., Soons and others 2005). To facilitate re-colonization of cleared areas, hay from target communities can be spread out to supply seeds and improve micro-environmental conditions. This has been successful in some situations (Poschlod and Biewer 2005; Coiffait-Gombault and others 2010), but is limited by the supply of hay from nearby source sites.

Many of these measures are unsuitable for application at a landscape scale and it would only be appropriate to apply them to sites of conservation importance or other targeted areas. Currently it falls to landowners to mitigate against the effects of $\mathrm{N}$ deposition. When conservation organizations are responsible for land management, such mitigation may be possible albeit expensive, but in many cases the land is owned by private individuals, so appropriate management needs to be promoted through agri-environment schemes. Mitigation measures to reduce the effect of $\mathrm{N}$ deposition are not currently incorporated into these schemes in many parts of Europe, but some of the measures described above are feasible at different scales. Farmers need incentives to encourage appropriate management.
Payment based on results of management, such as an increase in species richness or reduction in eutrophic species, could increase motivation and help farmers to value their land as a conservation resource but may reduce participation in the scheme if farmers are concerned about the probability of success.

\section{Emission Management Options}

Managing the effects of $\mathrm{N}$ deposition is frequently expensive, impractical and in some cases can change the landscape and the ecosystem dramatically. The only truly effective and sustainable method to reduce the impact of $\mathrm{N}$ is through the reduction of $\mathrm{N}$ emissions.

There are a number of potential methods that could be used to reduce emissions of $\mathrm{N}$. Emissions of $\mathrm{N}$ oxides from industrial sources are already controlled within Europe to a large extent through the legislation outlined above. However, this is not always the case world-wide. Options for the control of reduced $\mathrm{N}$ emissions from agriculture have poor uptake and oxidized $\mathrm{N}$ emissions from traffic and transport are mainly mitigated through efforts to reduce $\mathrm{CO}_{2}$ emissions.

In principle, the Habitats Directive provides protection for designated areas of conservation importance. Under the Directive, projects cannot be approved if they are assessed to have an adverse effect on a Special Area of Conservation (SAC) or Special Protection Area (SPA). However, this decision can only be made if an appropriate review and assessment is undertaken which, for many agricultural activities resulting in increased nitrogen deposition to nearby sites, is not the case. Legislative control of $\mathrm{N}$ emissions from agriculture, and indeed measuring and monitoring of emissions, provides many challenges due to the diffuse nature of emissions and the cost of emission reduction technology. Existing options for reducing $\mathrm{N}$ emissions from agriculture include direct injection of fertilizers and slurries, suitable storage of animal waste, utilizing technologies to minimize fertilizer use and filtering air before it leaves animal housing areas but all of these options have the potential to incur additional cost which may make them unattractive to farmers. Sutton and others (2011) suggest that improving the nitrogen use efficiency of crops through improving the genetic potential of crop varieties, increasing the genetic potential of animals to increase productivity, improving animal feed quality to increase feed conversion efficiency and increasing the efficiency of use of animal manures are key priorities to reduce agricultural $\mathrm{N}$ losses in Europe.

Workshop delegates suggested a number of possible options for reducing emissions. Diffuse nitrate pollution to water is currently controlled in Europe through the Nitrates 
Directive (91/676/EEC,) which requires Member States to identify areas where groundwater nitrate concentrations exceed $50 \mathrm{mg} \mathrm{l}^{-1}$ or are at risk of doing so. These areas are designated as Nitrate Vulnerable Zones (NVZs) and Member States must establish 'Action Programmes' in order to reduce and prevent further nitrate contamination. A similar approach could be taken to $\mathrm{N}$ emissions to the atmosphere.

Slurry spreading is an agricultural activity, which is currently managed for the protection of water quality, but could additionally be managed for air quality. For example, regulations in the UK (The Nitrate Pollution Prevention Regulations 2008) currently prohibit application of farmyard manure to grassland in NVZs between the mid-September and mid-January, when biological uptake is lowest and runoff is often high. If slurry spreading were also not permitted during the hottest months of the year, this would minimize ammonia volatilization.

Reduced meat production and the potential to educate the public to reduce meat consumption is an effective way to reduce ammonia emissions. World-wide meat consumption increased dramatically between 1961 and 1994, and although the rate of growth in per capita meat consumption has now slowed in the developed world, this is because it had already reached a very high level (Rosegrant and others 1999). Using incentives and education to reduce meat consumption could have environmental and health benefits. Initiatives such as 'meat free Mondays' (http://www. supportmfm.org/), meat free days in schools (such as seen in Ghent, Belgium), and government recommendations for reduced consumption of meat (such as seen in Sweden) are becoming increasingly popular and could reduce $\mathrm{N}$ emissions. Attendees at the workshop signed the 'Barsac declaration' (http://www.nine-esf.org/barsac-declaration) to reduce meat consumption encourage the availability of reduced meat portions.

Another suggestion proposed at the workshop was promoting grass-fed animals over housed ones, which generate higher ammonia emissions. The latter option has benefits for consumer health (e.g., Daley and others 2010), animal welfare and the management of the grasslands, since biomass is removed by grazing, but means that emissions cannot be managed by filtering $\mathrm{N}$ compounds from the air. "Green meat" (meat produced on high value grasslands) provides a further benefit of ensuring that grasslands of high value for nature conservation remain agriculturally productive and economically viable. A further option is to take measures to reduce population growth.

\section{Policy Questions for Research}

Results of study and personal observations have convinced policy makers and scientists from a range of countries and backgrounds at the workshop that $\mathrm{N}$ deposition is having an impact on species-rich acid grasslands in the Atlantic biogeographic region of Europe. However, there remain some important questions that require attention from scientists and policy makers in order for progress to be made toward providing greater protection for sensitive habitats.

\section{What Changes are of Conservation Concern?}

The evidence, briefly summarized above, shows a wide range of impacts on vegetation and soils, but there is a need to determine which of these changes are of conservation concern. For example, it may be that while changes in chemistry of plant tissues on a gradient of $\mathrm{N}$ deposition have the potential to provide an early warning of plant stress (Gidman and others 2006), it is likely to be of less concern in terms of the assessment and management of sites of conservation importance than changes in community structure and function. A reduction in plant species richness or a change in community composition may be of much greater concern, because it represents a loss of biodiversity. Of the changes that are considered of conservation concern in a particular habitat, it is necessary to determine which of these changes are the most important and which should trigger the need for action.

\section{How Much Change is Necessary for it to be Considered Significant?}

Once important changes have been identified, the magnitude of these changes needs to be considered. For example, Stevens and others (2004), in a gradient survey of acid grasslands in Great Britain, reported an average reduction in species richness of one species for every additional $2.5 \mathrm{~kg} \mathrm{~N}^{-1}$ year $^{-1}$ and suggested that this pattern was the result of long-term elevated $\mathrm{N}$ deposition. Given a response curve such as this, it is up to scientists and policy makers to determine 'acceptable' changes in community composition or reductions in species abundance or biodiversity before taking action. The dependence of ecosystem services on species diversity is a rapidly advancing research front (e.g., Engelhardt and Ritchie 2001) and will inform the extent to which species loss can be tolerated.

Addressing these questions will require close collaboration between scientists and policy makers and will provide a future direction for nitrogen-deposition research.

Acknowledgments This project was funded by the European Science Foundation through the EURODIVERSITY-programme, and national funds were provided by DfG (Germany), NERC (United Kingdom), NWO (The Netherlands) and INRA, ADEME and Aquitaine Region (France). We are grateful to workshop participants for their useful contributions. 


\section{References}

Achermann B, Bobbink R (2003) Empirical critical loads for nitrogen. In: Proceedings of the expert workshop, Berne, 11-13 November 2002. Swiss Department for the Environment, Forests and Landscape, Berne

Asman WAH, van Jaarsveld JA (2002) A variable-resolution transport model applied for $\mathrm{NHx}$ in Europe. Atmospheric Environment 26A:445-464

Blake L, Goulding KWT, Mott CJB, Johnston AE (1999) Changes in soil chemistry accompanying acidification over more than 100 years under woodland and grass at Rothamstead Experimental Station, UK. European Journal of Soil Science 50: 401-412

Bleeker A, Hicks WK, Dentener F, Galloway J, Erisman JW (2011) N deposition as a threat to the world's protected areas under the convention on biological diversity. Environmental Pollution 159:2280-2288

Bobbink R, Hornung M, Roelofs JGM (1998) The effects of air-borne nitrogen pollutants on species diversity in natural and seminatural European vegetation. Journal of Ecology 86:717-738

Bobbink R, Hicks K, Galloway J, Spranger T, Alkemade R, Ashmore M, Bustamante M, Cinderby S, Davidson E, Dentener F, Emmett B, Erisman JW, Fenn M, Gilliam F, Nordin A, Pardo L, De Vries W (2010) Global assessment of nitrogen deposition effects on terrestrial plant diversity: a synthesis. Ecological Applications 20:30-59

Buisson E, Holl KD, Anderson S, Corcket E, Hayes GF, Torre F, Peteers A, Dutoit T (2006) Effect of seed source, topsoil removal, and plant neighbour removal on restoring California coastal prairies. Restoration Ecology 14:569-577

Coiffait-Gombault C, Buisson E, Dutoit T (2010) Hay transfer promotes establishment of mediterranean steppe vegetation on soil disturbed by pipeline construction. Restoration Ecology 19:214-222

Daley CA, Abbott A, Doyle PS, Nader GA, Larson S (2010) A review of fatty acid profiles and antioxidant content in grass-fed and grain-fed beef. Nutrition Journal 9:1-12

De Graaf MCC, Verbeek PJM, Bobbink R, Roelofs JGM (1998) Restoration of species-rich dry heaths. The importance of appropriate soil conditions. Acta Botanica Neerlandica 47: $98-111$

Dentener F, Drevet J, Lamarque JF, Bey I, Eickout B, Fiore AM, Hauglustaine D, Horowitz LW, Krol M, Kulshrestha UC, Lawrence M, Galy-Lacaux C, Rast S, Shindell D, Stevenson D, Van Noije T, Atherton C, Bell N, Bergman D, Butler T, Cofala J, Collins B, Doherty R, Ellingsen K, Galloway J, Gauss M, Montanaro V, Müller JF, Pitari G, Rodriguez J, Sanderson M, Solmon F, Strahan S, Schultz M, Sudo K, Szopa S, Wild O (2006) Nitrogen and sulfur deposition on regional and global scales: a multimodel evaluation. Global Biogeochemical Cycles 20:1-21

Dorland E, Van den Berg LJL, Van den Berg AJ, Vermeer M, Roelofs JGM, Bobbink R (2004) The effects of sod cutting and additional liming on potential net nitrification in heathland soils. Plant and Soil 265:267-277

Dorland E, Hart MAC, Vermeer ML, Bobbink R (2005a) Assessing the success of wet heath restoration by combined sod cutting and liming. Applied Vegetation Science 8:209-311

Dorland E, van den Berg LJL, Brouwer E, Roelofs JGM, Bobbink R (2005b) Catchment liming to restore degraded, acidified heathlands and moorland pools. Restoration Ecology 13:302-311

Duprè C, Stevens CJ, Ranke T, Bleeker A, Peppler-Lisbach C, Gowing DJG, Dise NB, Dorland E, Bobbink R, Diekmann M (2010) Changes in species richness and composition in European acidic grasslands over the past 70 years: the contribution of cumulative atmospheric nitrogen deposition. Global Change Biology 16:344-357

EEA (2007) Halting the loss of biodiversity by 2010: proposal for a first set of indicators to monitor progress in Europe. European Environment Agency, Copenhagen

EEA (2008) Article 17 database. http://biodiversity.eionet.europa.eu/ article17/chapter9

Ellenberg H (1996) Vegetation Mitteleuropas mit den Alpen, 5th edn. Eugen Ulmer, Stuttgart

Engelhardt KM, Ritchie ME (2001) Effects of macrophyte species richness on wetland ecosystem functioning and services. Nature 411:687-689

Erisman JW, Bleeker A, Hensen A, Vermeulen A (2008) Agricultural air quality in Europe and the future perspectives. Atmospheric Environment 42:3209-3217

Eschen R, Mortimer SM, Lawson CS, Edwards AR, Brook AJ, Igual JM, Hedlund K, Schaffner U (2007) Carbon addition alters vegetation composition on ex-arable fields. Journal of Applied Ecology 44:95-104

European Commission (2006) Assessment, monitoring and reporting under Article 17 of the Habitats Directive: explanatory notes and guidelines. European Commission

Fagerli H, Aas W (2008) Trends of nitrogen in air and precipitation: model results and observations at EMEP sites in Europe, 1980-2003. Environmental Pollution 154:448-461

Falkengren-Grerup U (1995) Long-term changes in flora and vegetation in deciduous forests of southern Sweden. Ecological Bulletins 44:215-226

Fowler D, Smith R, Muller J, Cape JN, Sutton M, Erisman JW, Fagerli H (2007) Long term trends in sulfur and nitrogen deposition in Europe and the cause of non-linearities. Water Air and Soil Pollution Focus 7:41-47

Galloway JN, Townsend AR, Erisman JW, Bekunda M, Cai Z, Freney JR, Martinelli LA, Seitzinger SP, Sutton MA (2008) Transformation of the nitrogen cycle: recent trends, questions and potential solutions. Science 320:889-892

Galvánek D, Janák M (2008) Management of Natura 2000 habitats. $6230 *$ Species-rich Nardus grasslands. European Commission

Gauger T, Anshelm F, Schuster H, Erisman JW, Vermeulen AT, Draaijers GPJ, Bleeker A, Nagel H-D (2002) Mapping of ecosystem specific long-term trends in deposition loads and concentrations of air pollutants in Germany and their comparison with critical loads and critical levels. Institut fur Navigation, University of Stuttgart, Stuttgart

Gidman EA, Stevens CJ, Goodacre R, Broadhurst D, Emmett B, Gwynn-Jones D (2006) Loss of forb diversity in relation to nitrogen deposition in the UK: regional trends and potential controls. Global Change Biology 12:1823-1833

Hautier Y, Niklaus PA, Hector A (2009) Competition for light causes plant biodiversity loss after eutrophication. Science 324:636-638

Hejcman M, Klaudisová M, Hejcmanová P, Pavlů V, Jones M (2009) Expansion of Calamagrostis villosa in sub-alpine Nardus stricta grassland: cessation of cutting management or high nitrogen deposition? Agriculture Ecosystems and Environment 129: 91-96

Hejcman M, Schellberg J, Pavlů V (2010) Long-term effects of cutting frequency and liming on soil chemical properties, biomass production and plant species composition of LolioCynosuretum grassland after the cessation of fertilizer application. Applied Vegetation Science 13:257-269

ICP Modelling and Mapping (2004) Manual on methodologies and criteria for mapping critical levels/loads and geographical areas where they are exceeded. Report UBA-Texte 52/04. http:// icpmapping.org/ 
Jansen AJM, Roelofs JGM (1996) Restoration of Cirsio-Molinietum wet meadows by sod cutting. Ecological Engineering 7:279-298

Johnston AE, Goulding KWT, Poulton PR (1986) Soil acidification during more than 100 years under permanent grassland and woodland at Rothamstead. Soil Use and Management 2:3-10

Jones AT, Hayes MJ (1999) Increasing floristic diversity in grassland: the effects of management regime and provenance on species introduction. Biological Conservation 87:381-390

Krahulec F (1985) The chorologic pattern of European nardus-rich communities. Vegetatio 59:119-123

Mace G, Masundire H, Baille J (2005) Biodiversity, Millennium Ecosystem Assessment. Island Press, Washington

Maskell LC, Smart SM, Bullock JM, Thompson K, Stevens CJ (2010) Nitrogen deposition causes widespread species loss in British habitats. Global Change Biology 16:671-679

NEGTAP (2001) Transboundary air pollution: acidification, eutrophication and ground-level ozone in the UK. CEH, Edinburgh

Netherlands Environmental Assessment Agency (2005) Environmental data compendium: nitrogen deposition in the Netherlands, 2001. http://www.mnp.nl/mnc/i-en-0189.html

Nilsson J, Grennfelt PE (1988) Critical loads for sulphur and nitrogen. UNECE/Nordic Council of Ministers, Copenhagen

Olff H, Bakker JP (1991) Long-term dynamics of standing crop and species composition after the cessation of fertiliser application to mown grassland. Journal of Applied Ecology 28:1040-1052

Pieterse G, Bleeker A, Vermeulen AT, Wu Y, Erisman JW (2007) High resolution modelling of atmosphere-canopy exchange of acidifying and eutrophying components and carbon dioxide for European forests. Tellus 59B:412-424

Poschlod P, Biewer H (2005) Diaspore and gap availability are limiting species richness in wet meadows. Folia Geobotanica 40:13-34

Pywell RF, Bullock JM, Hopkins A, Walker KJ, Sparks T, Burke MJW, Peel S (2002) Restoration of species-rich grassland on arable land: assessing the limiting processes using a multi-site experiment. Journal of Applied Ecology 39:294-309

Roelofs JGM, Bobbink R, Brouwer E, De Graaf MCC (1996) Restoration ecology of aquatic and terrestrial vegetation on noncalcareous sandy soils in The Netherlands. Acta Botanica Neerlandica 45:517-541

Rosegrant MW, Leach N, Gerpacio RV (1999) Alternative futures for world cereal and meat consumption. Proceedings of the Nutrition Society 58:219-234

Sala OE, Chapin FS, Armesto JJ, Berlow E, Bloomfield J, Dirzo R, Huber-Sanwald E, Huenneke LF, Jackson RB, Kinzig A, Leemans R, Lodge DM, Mooney HA, Oesterheld M, Poff NL, Sykes MT, Walker BH, Walker M, Wall DH (2000) Biodiversity-global biodiversity scenarios for the year 2100 . Science 287:1770-1774

Schwickerath M (1944) Das Hohe Venn und seine Randgebiete. Pflanzensoziologie 6:1-278

Sikor T (2003) The commons in transition: agrarian and environmental change in Central and Eastern Europe. Environmental Management 34:270-280

Silvertown J, Dodd ME, McConway K, Potts J, Crawley M (1994) Rainfall, biomass variation, and community composition in the Park Grass experiment. Ecology 75:2430-2437

Smith RI, Fowler D, Sutton MA, Flechard C, Coyle M (2000) Regional estimation of pollutant gas dry deposition in the UK: model description, sensitivity analyses and outputs. Atmospheric Environment 34:3757-3777

Soons MB, Messelink JH, Jongejans E, Heil GW (2005) Habitat fragmentation reduces grassland connectivity for both shortdistance and long-distance wind-dispersed forbs. Journal of Ecology 93:1214-1225
Stevens CJ, Dise NB, Mountford JO, Gowing DJ (2004) Impact of nitrogen deposition on the species richness of grasslands. Science 303:1876-1879

Stevens CJ, Maskell LC, Smart SM, Caporn SJM, Dise NB, Gowing DJ (2009) Identifying indicators of atmospheric nitrogen deposition impacts in acid grasslands. Biological Conservation 142:2069-2075

Stevens CJ, Duprè C, Dorland E, Gaudnik C, Gowing DJG, Bleeker A, Diekmann M, Alard D, Bobbink R, Fowler D, Corcket E, Mountford JO, Vandvik V, Aarrestad PA, Muller S, Dise NB (2010a) Nitrogen deposition threatens species richness of grasslands across Europe. Environmental Pollution 158:2940-2945

Stevens CJ, Thompson K, Grime JP, Long CJ, Gowing DJG (2010b) Contribution of acidification and eutrophication to declines in species richness of calcifuge grasslands along a gradient of atmospheric nitrogen deposition. Functional Ecology 24:478-484

Stevens CJ, Dupre C, Gaudnik C, Dorland E, Dise NB, Gowing DJ, Bleeker A, Alard D, Bobbink R, Fowler D, Corcket E, Vandvik V, Mountford JO, Aarrestad PA, Muller S, Diekmann M (2011a) Changes in species composition of European acid grasslands observed along a gradient of nitrogen deposition. Journal of Vegetation Science 22:207-215

Stevens CJ, Duprè C, Dorland E, Gaudnik C, Gowing DJG, Bleeker A, Diekmann M, Alard D, Bobbink R, Fowler D, Corcket E, Mountford JO, Vandvik V, Aarrestad PA, Muller S, Dise NB (2011b) The impact of nitrogen deposition on acid grasslands in the Atlantic region of Europe. Environmental Pollution 159: 2243-2250

Sutton MA, Howard CM, Erisman JW, Billen G, Bleeker A, Grennfelt P, van Grinsven H, Grizzetti B (2011) The European nitrogen assessment. Cambridge University Press, Cambridge

ter Braak CFJ, Smilauer P (2002) CANOCO 4.5, 4.5 ed. Biometris, Wargeningen

Tilman D (1999) Global environmental impacts of agricultural expansion: the need for sustainable and efficient practices. Proceedings of the National Academy of Sciences of the United States of America 96:5995-6000

Török K, Szili-Kovacs T, Halassy M, Toth T, Hayek Z, Paschke MW, Wardell LJ (2000) Immobilization of soil nitrogen as a possible method for the restoration of sandy grassland. Applied Vegetation Science 3:7-14

Tyler G, Olsson T (2001) Concentrations of 60 elements in the soil solution as related to soil acidity. European Journal of Soil Science 52:151-165

van den Berg LJL, Dorland E, Vergeer P, Hart MAC, Bobbink R, Roelofs JGM (2003a) Decline of acid-sensitive plant species in heathland can be attributed to ammonium toxicity in combination with low pH. New Phytologist 166:551-564

van den Berg LJL, Vergeer P, Roelofs JGM (2003b) Heathland restoration in The Netherlands: effects of turf cutting depth on germination of Arnica montana. Applied Vegetation Science 6:117-124

Van Jaarsveld JA (1995) Modelling the long-term atmospheric behaviour of pollutants on various spatial scales. University of Utrecht, Utrecht

Van Jaarsveld JA (2004) The operation priority substances model. National Institute for Public Health and the Environment (RIVM), Bilthoven

Walker KJ, Stevens PA, Stevens DP, Mountford JO, Manchester SJ, Pywell RF (2003) The restoration and re-creation of species rich lowland grassland on land formerly managed for intensive agriculture in the UK. Biological Conservation 119:1-18

Wilson EJ, Wells TCE, Sparks TH (1995) Are calcareous grasslands in the UK under threat from nitrogen deposition?-an experimental determination of a critical load. Journal of Ecology 83:823-832 